\title{
Heart inflammation in perch Perca fluviatilis and roach Rutilus rutilus from central Finland
}

\author{
Ahti Haaparanta ${ }^{1}$, E. Tellevo Valtonen ${ }^{1}$, Rudolf W. Hoffmann ${ }^{2}$ \\ ${ }^{1}$ Department of Biology, University of Jyväskylä, SF-40100 Jyväskylä, Finland \\ ${ }^{2}$ Institut für Zoologie und Hydrobiologie, Tierärztliche Fakultät der Universität München, D-80539 Munich, Germany
}

\begin{abstract}
Local inflammation of the heart was found in about $20 \%$ of both perch Perca fluviatilis and roach Rutilus rutilus from 4 lakes in central Finland during 1989-1990. The lakes differ in their trophic state and pollution level. Epicarditis was found more often than myocarditis ( $22 \%$ in perch and $18.4 \%$ in roach vs 16.1 and $5.4 \%$, respectively). Most cases of epicarditis found in perch were chronic $(86 \%)$, but only a minority of those in roach were so $(24 \%)$, the others being acute, subacute or subchronic. Myocarditis was nearly always chronic in both species. No relationship was found between the stage or degree of inflammation in the fish and the pollution level in the lake, and all stages of inflammation were found at all seasons with no significant seasonal trend in their prevalence, nor was any relationship found between the prevalence of inflammation and the size of the fish in any of the lakes. Myocarditis and epicarditis occurred independently of each other in roach, but their joint occurrence in individual fish differed significantly from the random in perch, showing a positive correlation. Macrophage centres were found in $16 \%$ of the epicardium specimens and $24 \%$ of the myocardium specimens from perch and in 8.7 and $7.8 \%$ from roach, respectively, as well as in the bulbus arteriosus and atrium of both species. No causative agent, such as parasites or bacteria, was ever seen to be associated with either the inflammation or the macrophage centres. The reason for the inflammation is discussed.
\end{abstract}

KEY WORDS: Heart inflammation Perch - Roach

\section{INTRODUCTION}

Our current knowledge of the structure of the fish heart has been acquired through morphological descriptions and the study of fish diseases. The idea of the fish heart as a typical venous type is said to be an oversimplified generalization (Tota et al. 1983), and heterogeneity among fish groups or species has, in fact, been found to be great with respect to both the blood circulation and the morphology of the heart (Tota et al. 1983, Santer 1985).

An inflammatory reaction is the basic protective response to tissue damage in all vertebrates. If an acute inflammatory lesion does not resolve quickly, chronic inflammation follows, frequently with the formation of granulomas (Roberts 1989). The occurrence of heart lesions in wild populations of fish has not been studied, but many agents are known to cause damage to the fish heart (see Ferguson 1989, Roberts 1989). In order to assess the state of the heart in free-living fish popu- lations, or in fish farms from the standpoint of therapy and in other respects, it is important that heart lesions be properly recognized.

In a preliminary histological investigation of the heart of roach Rutilus rutilus (L.) and perch Perca fluviatilis (L.) in 4 lakes in central Finland we found inflammations and macrophage centres in both the myocardium and the epicardium of both species. However, we were unable to find any causative agent for these. Since 3 of the lakes are eutrophic, including one which is also polluted by effluent from pulp and paper mills, we were interested in investigating whether these findings might be connected with the pollution and eutrophication of the lakes. Reference samples were collected from an oligotrophic lake which appears to be in a natural state. The purpose of this research was to examine the incidence of heart inflammations in wild fish populations and to look for relationships with infectious agents or pollution. 


\section{STUDIED LAKES}

The chain of 3 lakes plus a further one connected to them is located in central Finland and forms part of the Kymijoki River system, the waters of which flow into the Gulf of Finland (Fig. 1). Lakes Vatia, Saravesi and Leppävesi are eutrophic. Lake Vatia is polluted by effluent from paper and pulp mills, and traces of pollutants have also been detected in Saravesi and Leppävesi

Reference fish material was collected from the unpolluted oligotrophic Lake Peurunka, which is the largest and deepest of the lakes studied here and has the slowest water turnover, whereas the highest levels of water replacement ( 3 and $4 \mathrm{~d}$, respectively) occur in Lakes Vatia and Saravesi (see also BrummerKorvenkontio et al. 1991). The lakes are covered with ice from 20-25 November until 10 May on average. The highest water temperatures are reached at the end of July and the beginning of August (18 to $20^{\circ} \mathrm{C}$ ).

Water from the oligotrophic Lake Peurunka flows into the polluted Lake Vatia. Three obstacles to fish migration between the lakes exist. A dam was built in the 1960 s in connection with a fish farm situated between the 2 lakes, a powerful stretch of rapids occurs between Lake Vatia and the eutrophic Lake Saravesi and a hydroelectric power station was installed between the eutrophic Lakes Saravesi and Leppävesi (Fig. 1).

The pollution of the eutrophic Lake Vatia is due to pulp and paper mill effluent originating $15 \mathrm{~km}$ upstream, and the concentration of organochlorine com- pounds in the rapids between it and Lake Saravesi is still $200 \mathrm{\mu g} \mathrm{l}^{-1}$ (Paasivirta et al. 1988). The polluted nature of Lake Vatia is also seen in its benthic quality index (Wiederholm 1980), which is zero in the deepest areas and 0.75 elsewhere (scale 0 to 5) (Granberg et al. 1987a). Phytoplankton primary production has increased in all of the lakes except Lake Peurunka, indicating eutrophication, e.g. chlorophyll a levels of 12.5 and $9.99 \mathrm{~g} \mathrm{I} \mathrm{l}^{-1}$ in Lakes Vatia and Leppävesi, respectively (Granberg et al. 1987b).

At least 14 freshwater fish species occur in all of the lakes, of which roach and perch are the most common throughout. Other cyprinids such as bream Abramis brama (L.) and ide Leuciscus idus (L.) are more common in the eutrophic lakes than in the oligotrophic one, where there are also 2 coregonid species, the vendace Coregonus albula L. and the whitefish Coregonus $s p$. No drastic differences between the lakes in the relative abundances of the fish species have been reported (Granberg et al. 1987a, b)

\section{MATERIAL AND METHODS}

A total of 150 perch and 169 roach from the 4 lakes were examined in autumn 1989 and winter, spring, summer and autumn 1990. The fish were killed by cutting the medulla spinalis behind the head, and their hearts were promptly fixed in $10 \%$ buffered formalin and routinely embedded in paraffin (melting point 56 to $58^{\circ} \mathrm{C}$ ). Sections $(5$ to $6 \mu \mathrm{m}$ ) were stained with

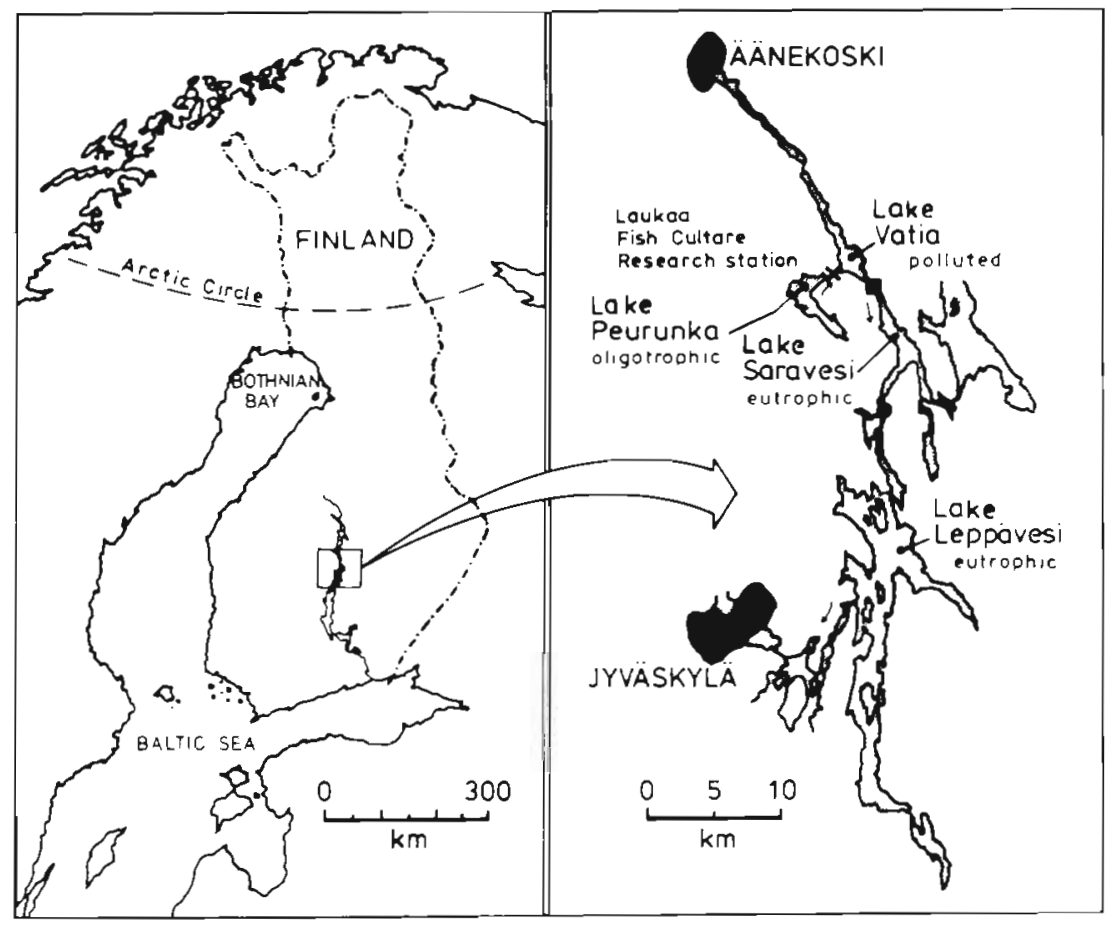

Fig. 1. The 4 lakes studied. Lake Peurunka is oligotrophic, Lake Vatia is eutrophic and polluted, and Lakes Saravesi and Leppävesi are eutrophic. (x) dam; (-) strong rapids; $(\bullet)$ hydroelectric power station 
Harris-H\&E and Giemsa stains, in addition to which the periodic acid Shiff reaction combined with alcian blue (AB-PAS) and Ziehl-Neelsen staining were performed. The ventricle and bulbus arteriosus were studied systematically, but the atrium was sometimes lost in the process

\section{RESULTS}

Various stages of inflammation could be detected in about $20 \%$ of fish in both species. A characteristic feature was the focal nature of most inflammations (Fig. 2), which could be seen in about $90 \%$ of all cases. The following types could be differentiated with regard to the location and age of the inflammation.

\section{(1) Myocarditis:}

Acute: local infiltration of the myocardial fibres by heterophilic granulocytes, at least 5 to 10 cells.

Subacute: heterophils, lymphocytes and macrophages are distributed within the focus.

Chronic: lymphocytes and macrophages dominate, and heterophils occur only very rarely.

Myocarditis was found especially in the ventricle layers or in the atrium, whereas the bulbus arteriosus was less frequently affected. Multifocal inflammation could be identified in some cases.

\section{(2) Epicarditis:}

Identical types of inflammation were observed on or under the epicardial layer as in the myocardium. The formation of granulomatous areas with a framework of proliferating capillaries was common in chronic stages, however (Fig. 3).

(3) Formation of macrophage centres:

Pigment-bearing, yellowish macrophage centres, often containing amorphic, partially acid-fast material (ceroid) and epithelioid cells, tended to form in both locations and were bordered by fibrocytes. Ceroid macrophages predominated in the early centres, whereas epithelioid cells were more common in the older ones. Furthermore, the young macrophage centres often lacked the bordering wall of fibrocytes, or else it consisted of only one layer, whereas the older ones had up to 3 cell layers separating the macrophages from the surrounding tissue. The macrophage centres were regarded as representing the final stage of the inflammatory reaction (Fig. 4)

Both myocarditis and epicarditis were recorded in the hearts of perch and roach. Most of the epicarditis found in perch was chronic $(85.7 \%), 8.6 \%$ being subchronic and $5.7 \%$ subacute. No acute infection was found in perch. The situation was different in roach, however, where the proportions of acute, subacute and

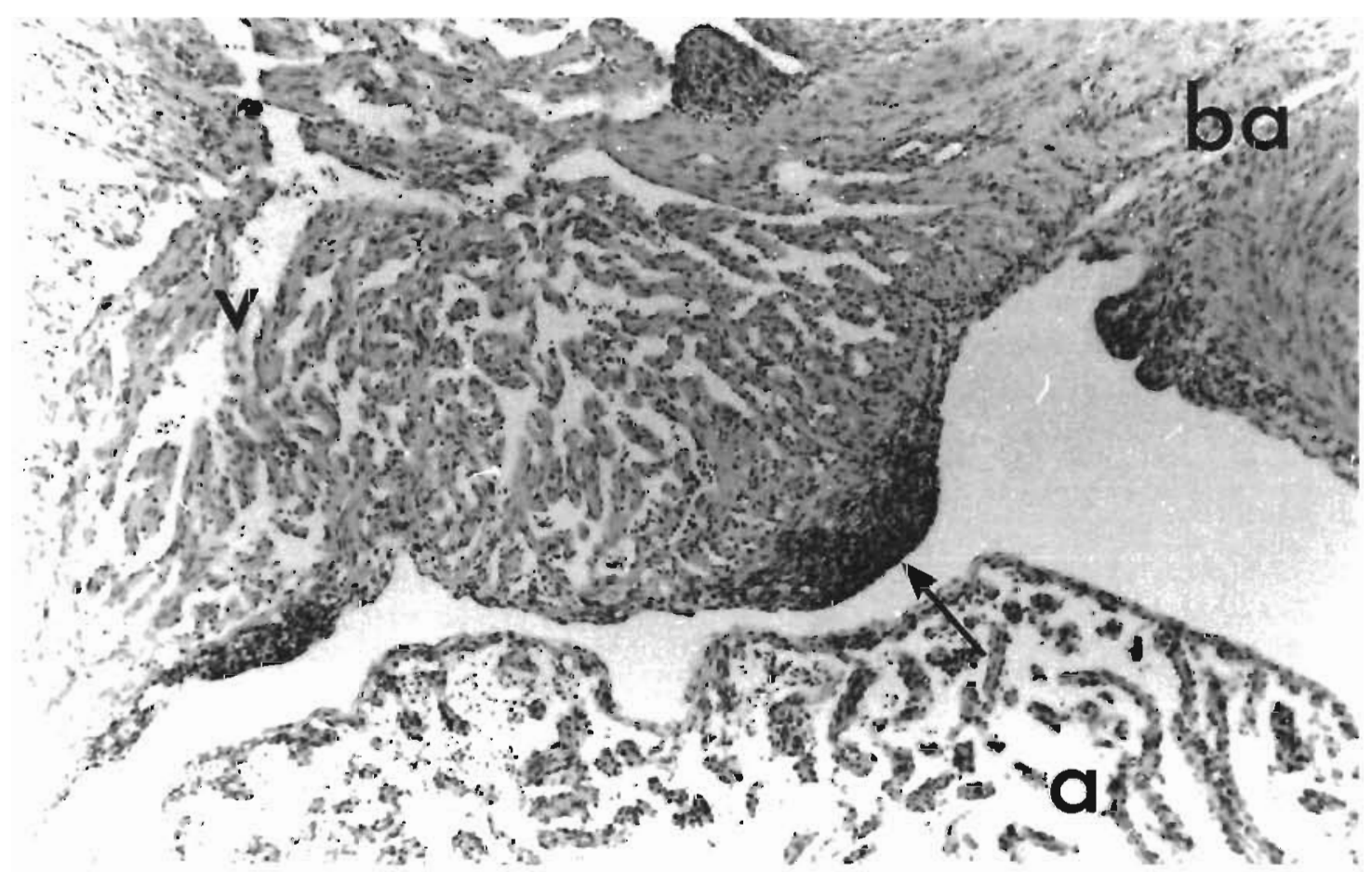

Fig. 2. Perca fluviatilis. Heart of a perch with focal epicarditis (arrows) ba: bulbus arteriosus; v: ventricula; a: atrium. H\&E, 80X 


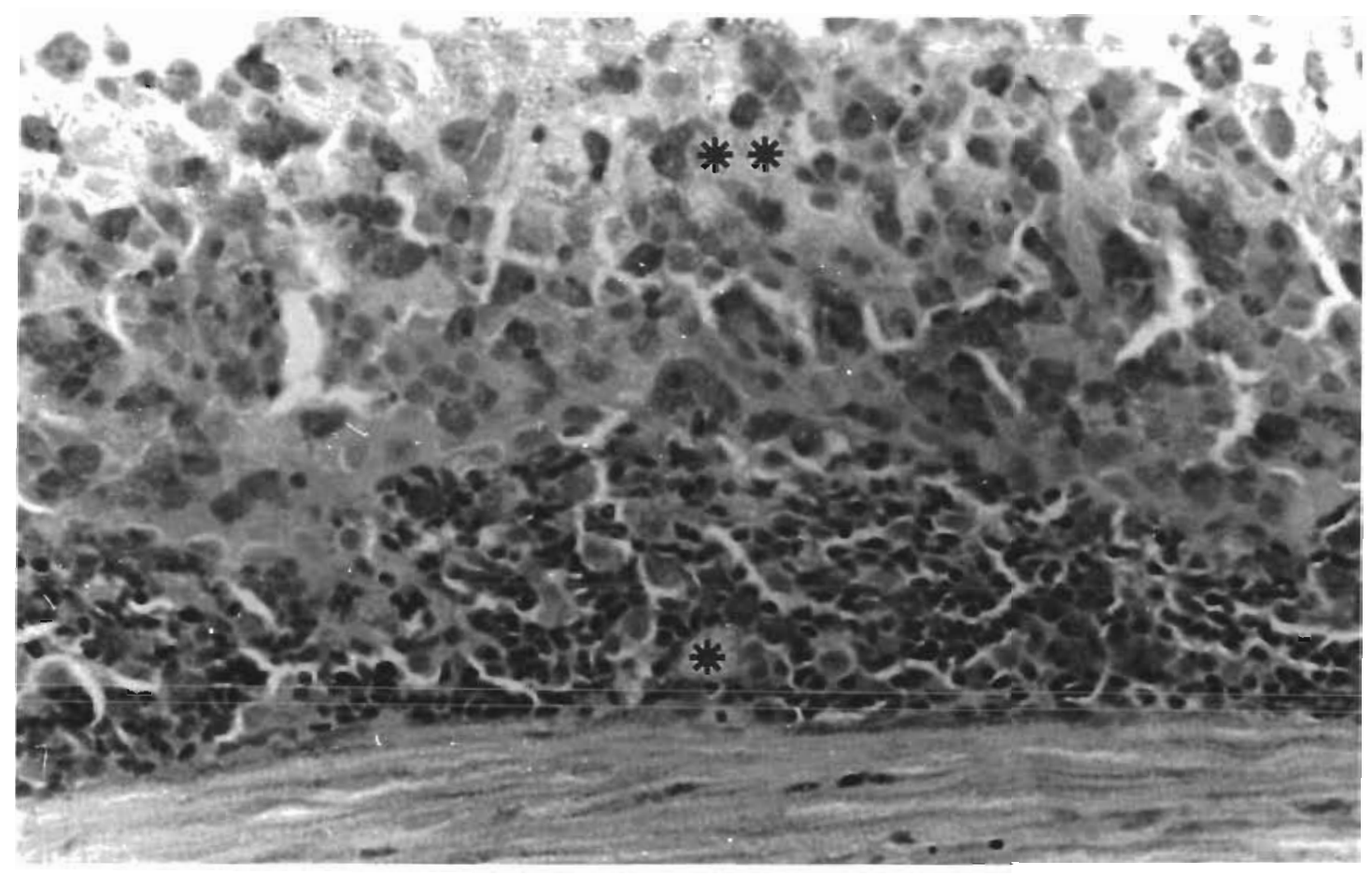

Fig. 3. Rutilus rutilus. Acute to subacute epicarditis in the heart of a roach from Lake Leppävesi, October 1989. The layer consists mostly of lymphocytes $(*)$ and an outer layer of granulocytes (**). AB-PAS, 450x

subchronic infections were $21.1,36.8$ and $18.4 \%$ respectively, and that of chronic infections only $23.7 \%$.

Myocarditis was chronic in all cases in both fish species, except for one focal acute inflammation in a roach. No correlation was found between the stage of inflammation and the pollution level of the lake, and all stages of inflammation were found at all seasons, with no systematic variation.

Myocarditis and epicarditis occurred independently of each other in the roach $\left[\chi^{2}\right.$ (Yates) $=16.953, p=$ 0.984 ], but their joint occurrences in individual fish specimens differed from a random distribution in the perch $\left[\chi^{2}\right.$ (Yates) $\left.=7.117, p=0.008\right]$, showing a positive correlation.

Epicarditis was found more often than myocarditis in both fish species in the pooled material from all seasons and lakes, $22 \%$ and $18.4 \%$ of the perch and roach being affected, respectively, while the corresponding values for myocarditis were $16.1 \%$ and $5.4 \%$. The occurrence of myocarditis was significantly higher in perch than in roach (Yates' corrected $\chi^{2}$ test, $\chi^{2}=6.501$, $p=0.011$, but the difference in epicarditis between the species was not significant $\left[x^{2}\right.$ (Yates $]=0.000$, $\mathrm{p}=1.000$ ) (Fig. 5)

No correlation was found between the occurrence of myocarditis or epicarditis and the length of either the perch or the roach in any of the lakes (likelihood ratio test, $\chi^{2}=9.772, p=$ at least 0.082 )
The prevalences of inflammation of both types in the 4 lakes are given separately in Fig. 5. Epicarditis was more common than myocarditis in perch from the 3 altered lakes (Vatia, Saravesi and Leppävesi), but the difference was statistically significant only in Lake Leppävesi. The prevalence of epicarditis did not differ significantly between the lakes in either perch (likelihood ratio test, $\left.\chi^{2}=5.4, p=0.148\right)$ or roach $\left(x^{2}=5.2\right.$, $p=0.156$ ), whereas in the case of myocarditis in perch a significant difference was revealed between the lakes (likelihood ratio test, $x^{2}=8.687, p=0.034$ ), which was due to a greater prevalence in Lake Saravesi and a lower prevalence in Lake Leppävesi. No statistically significant difference in the occurrence of myocarditis in roach was found between the lakes $\left(\chi^{2}=2.892\right.$, $p=0.409$ ), although the highest occurrence was found in Lake Saravesi.

The results for the 4 lakes regarding the seasonality of heart inflammations were pooled (Fig. 6). Inflammations of both types were most common in the perch in October 1990, but increased epicarditis was also found during the previous autumn. The seasonal differences in the occurrence of epicarditis were nevertheless not statistically significant in ejther perch (likelihood ratio test, $\chi^{2}=5.302, p=0.258$ ) or roach $\left(x^{2}=2.97, p=0.562\right)$. The occurrence of myocarditis in both fish species increased in autumn 1990, and the differences were significant (likelihood ratio test, 


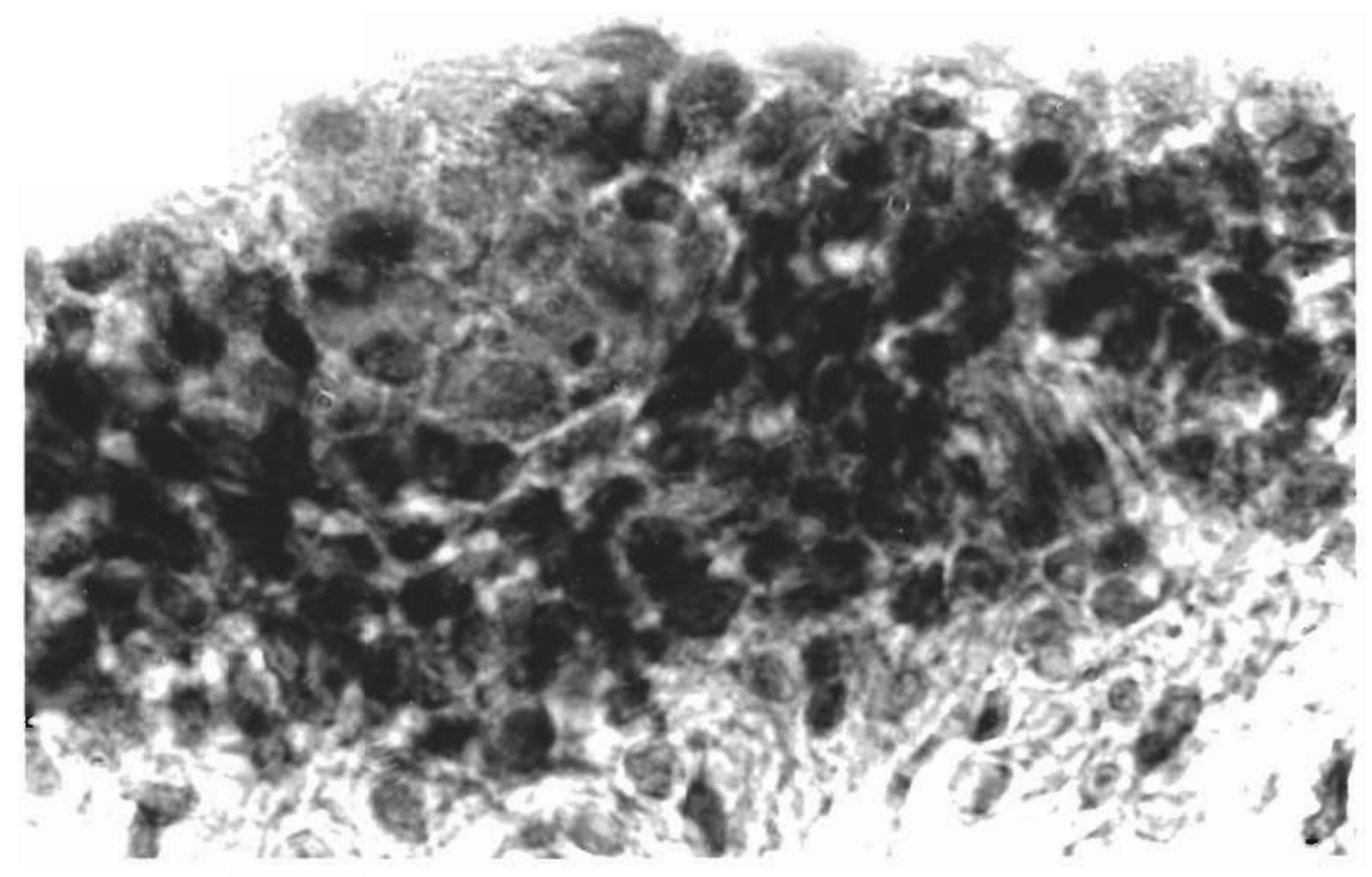

Fig. 4. Perca fluviatilus. A small macrophage centre in the epicardium of a perch, surrounded by lymphocytes. H\&E, 1640x
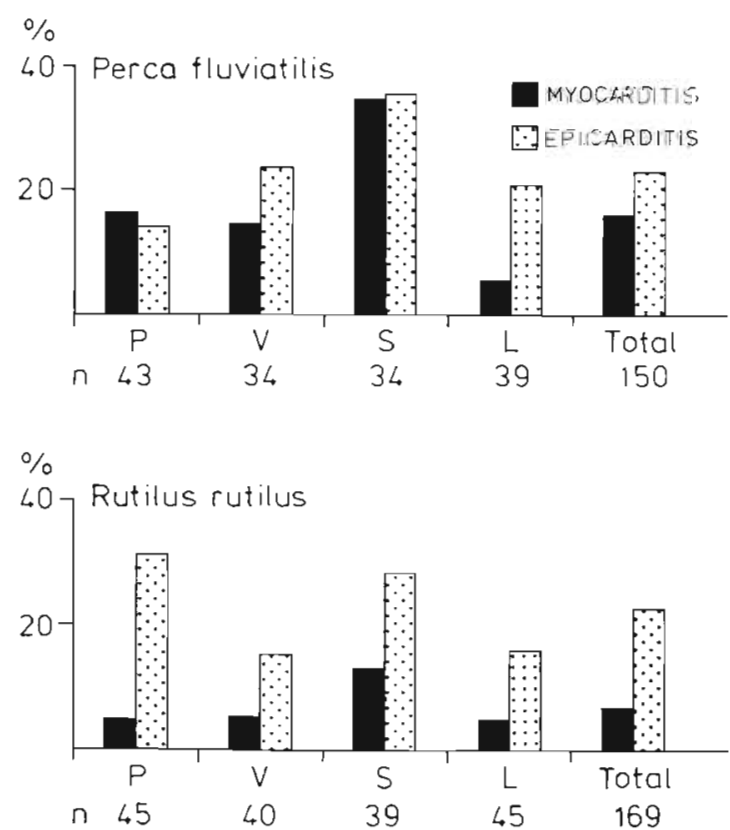

Fig. 5. Perca fluviatilis and Rutilus rutilus. Occurrence (\%) of myocarditis and epicarditis in the hearts of perch and roach from 4 lakes in central Finland from October 1989 to October 1990. Numbers of fish studied are also given. $\mathrm{P}=$ Lake Peurunka, $\mathrm{V}=$ Lake Vatia, $\mathrm{S}=$ Lake Saravesi, $\mathrm{L}=$ Lake Leppävesi
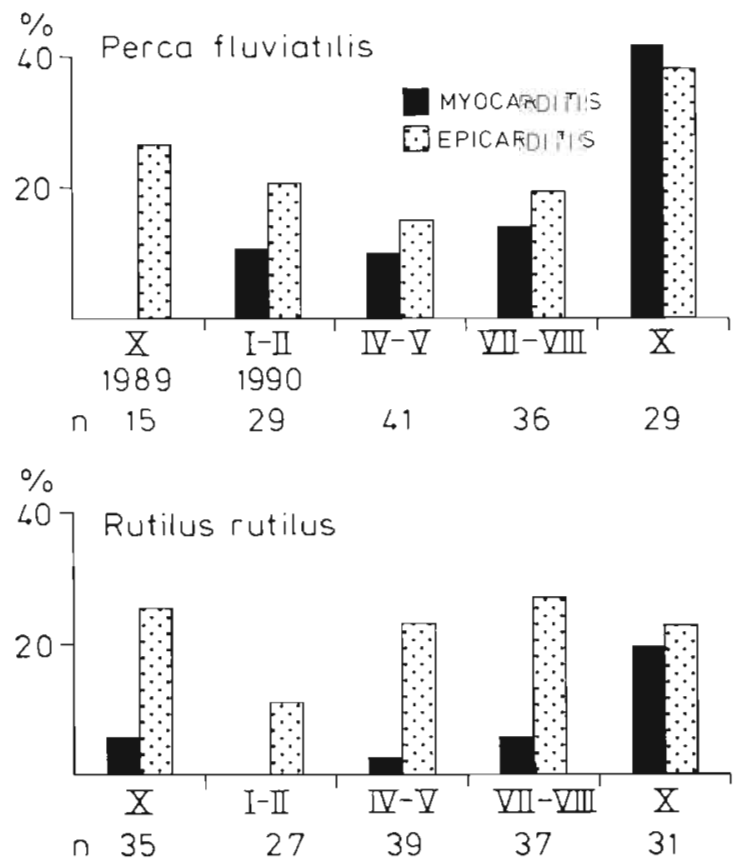

Fig. 6. Perca fluviatilis and Rutilus rutilus. Seasonal occurrence of myocarditis and epicarditis (\%) in perch and roach from central Finland. Numbers of fish studied in each season are given under the figure. Months indicated by Roman numerals 
$x^{2}=17.906$ and 10.715, $\mathrm{p}=0.001$ and 0.030 , for perch and roach respectively).

Macrophage centres were found in $16 \%$ and $24.1 \%$ of the epicardium and myocardium samples from perch and $8.7 \%$ and $7.8 \%$ respectively from roach. Both inflammation types were found in both fish species in all the lakes, without any relation to pollution level or season. Macrophage centres were also found in $8.0 \%$ and $15.7 \%$ of the bulbus arteriosus specimens and $19.3 \%$ and $6.6 \%$ of the atrium specimens from perch and roach, respectively. When macrophage centres were found in the atrium of a perch there were numerous centres present, sometimes more than 10 centres in one section, whereas no more than 1 to 2 per fish were found in other parts of the heart. No causative agents, e.g. parasites or bacteria, were ever identified.

\section{DISCUSSION}

Most fish have a spongy, trabeculated ventricular myocardium (spongiosa) supplied by the venous blood of the intertrabecular spaces (lacunae). In many species the spongiosa is covered by an outer layer of densely arranged myocardial bundles (compacta). The spongy core of the ventricle is supplied by lacunary venous blood, and the compact outer shell by capillaries derived from either coronaries or extracoronary sources ('caudal' vessels) (Grant \& Regnier 1926, Cimini et al. 1977, Tota et al. 1983, Santer 1985). The heart of perch and roach represents this 'mixed type of ventricular myocardium'.

The heart is a target organ for many bacterial diseases, notably those due to Aeromonas salmonicida and Renibacterium salmoninarum, and also some viral diseases. Viral haemorrhagic septicemia (VHS), for example, can cause multifocal myocarditis. The heart is also a preferred site for the fungus Ichthyophonus hoferi, which causes granulomatous epicarditis and myocarditis in a number of fish species. Some parasite species such as myxosporean protozoans, trematode metacercariae (e.g. Ichthyocotylurus species) and some copepods, e.g. Lernaeocera branchialis, can also penetrate the heart tissue and harm the fish (Ferguson 1989), as can the sanguinicolid Pearsonellum corventum (Overstreet \& Køie 1989, Overstreet \& Thulin 1989). Epicarditis has been found to be associated with myxosporean-induced swim bladder inflammation in fry of the common carp, but no parasitic stages could be identified (Körting et al. 1984)

The lack of a causative agent associated with epicarditis or myocarditis in either fish species in any of the present cases may not be surprising, since a high proportion of chronic stages could be observed, in which the initiating agent may no longer be present. Myxosporean blood stages were thought to be present in a few cases, but no developed plasmodia or spores were noted in the heart. The 2 fish species have been examined thoroughly for all parasites in these 4 lakes, and 10 myxosporean species have been found in the roach, of which only Myxidium rhodei was found in $0.6 \%$ of the roach hearts from Lake Peurunka in squash preparations, and none from other lakes (Brummer-Korvenkontio et al. 1991). Ichthyocotylurus variegata was a common species in the inner organs of perch, and also occurred incidentally in the heart (Valtonen unpubl.). No I. variegata or M. rhodei infection of the heart was seen in the histological material, however.

No signs of bacterial infections could be observed, but even here it is more common for myocardial lesions to be induced by toxins than by local infection with the presence of bacteria.

The high percentage of fish showing chronic inflammatory changes is not surprising if one considers the function of the heart as an immunological barrier in fish, in contrast to higher vertebrates (e.g. Roberts 1989). The endocardial cells covering the myocardium are able to phagocytize, especially in the atrium, which can filter foreign bodies such as parasites, bacteria and viruses from the blood stream. The observed lesions, which were morphologically very similar, may therefore have been induced by different causative agents. In contrast to infectious conditions such as vibriosis, furunculosis, VHS or Ichthyophonus hoferi infection, no research exists into the occurrence of cardiac lesions in normal free-living fish populations, and therefore it is impossible to say whether the percentage described here is in the normal range or elevated. Random collection representing 10 cyprinid species from eutrophic rivers in Germany yielded a comparably high percentage of cardiac lesions. However, in these cases parasites (Sanguinicola sp. and myxosporeans) could be detected in some of the fish, but in most of them no pathogenic agent was detectable (Hoffmann unpubl.).

The fact that no statistically significant differences were found between the lakes in the occurrence of inflammations, except in the case of myocarditis in perch, is also interesting. After the preliminary survey in which heart inflammations were observed in the fish, we expected to find more inflammations in fish from the 3 altered lakes than from the oligotrophic lake. According to Wedemeyer (1976), changes in water quality and other environmental factors may suppress the immune system of fish and increase their vulnerability to invading pathogens. The chemotactic activity of macrophages isolated from the kidneys of 2 fish species in Elisabeth River (Chesapeake Bay, 
Virginia, USA) had decreased compared with controls from the unpolluted York River, suggesting a connection with exposure. Activity returned to normal after the fish were kept in clean water for 3 wk (Weeks et al. 1986). Valtonen \& Koskivaara (1989) found significant differences among the present lakes in their parasite fauna and parasite abundances, e.g. trematode occurrences were low in Lake Vatia, and some ectoparasitic protozoans occurred in increased numbers in all 3 altered lakes. There are also indications that the immunological response of roach in Lake Vatia is significantly reduced as compared with unpolluted Lake Peurunka (T. Aaltonen, E. J. Jokinen \& E. T. Valtonen unpubl.)

Activated macrophages produce soluble factors which serve to marshal host defences against injury or inflammation (Dinarello 1989). One reason for the abundance of macrophage centres here may be the high percentage of chronic inflammations with lymphocytic infiltration, as T-lymphocytes are known to produce macrophage activating factor (MAF) in vitro (Graham \& Secombes 1990). The macrophages themselves are the initial step in the defense system and are able to phagocytize and degrade organic material after ingestion (Braun-Nesje et al. 1982).

Macrophages can be found in most soft tissues of fish, and pigmented macrophages are well dispersed in more primitive fish such as salmonids (Agius 1980 , 1981). In contrast, higher fishes have discrete aggregations of pigmented macrophages termed 'macrophage centres'. These structures can vary in size according to the fish species (Roberts 1975). Little is known about macrophage centres in the fish heart, but more information exists with regard to their presence in other organs, especially the kidney and spleen (see Agius $1980,1981,1985)$. It is possible that macrophage centres in the heart have simply been ignored by many researchers. On the other hand, the free nature of these cells means that they are present only occasionally, e.g. when a foreign body is recognized. Macrophage centres can also vary in number and size over a wide range. Probably a large number of fish from different environmental circumstances would be needed to resolve the question of whether or not they exist in the heart of other fish species. Since macrophages have the ability to migrate towards a stimulus (Weeks et al. 1986), it can be assumed that a fish heart infected by parasites will be more likely to possess macrophage centres than one without them. It has recently been suggested that macrophage centres are a common feature in the hearts of digenean-infected, and possibly all, serranids (Overstreet \& Thulin 1989).

The occurrence of macrophage centres was more common in the epicardium than in the myocardium. Ferguson (1989) reports the epicardium to be a fa- voured place for granulomas. It can be hypothesised that the epicardium may be more easily exposed to disturbing factors than the myocardium, or that the myocardium, consisting mostly of myofibrils, represents a tissue of little importance for utilization by pathogens, whereas more fat can be found in the epicardium. Another possibility would be that foreign bodies or infectious agents may be removed better and faster from the heart muscle, which is well perfused by blood, than from the peripheral pericardial or subendocardial regions, where only relatively few small blood vessels are present. These agents must therefore be destroyed in loco, whereas those in the muscle region can easily be transmitted from the heart ventricle to the spleen or other immuno-competent regions via the blood stream.

It also is possible that even our oligotrophic lake, which is still considered to be in a natural state by normal criteria, is no longer so, as we have found shortduration proliferations in gills and fusions of secondary lamellae in both of these fish species during the time of meltwater influx in spring and during the autumn rains (unpubl.). It is thus possible that none of our 4 lakes is completely unaltered in terms of such a delicate system as the histological structure of the heart. Water quality changes or other related factors could also be partly responsible for the heart inflammations and the occurrence of macrophage centres in the heart.

Acknowledgements. This study was financed by the Research Council for the Environmental Sciences, Academy of Finland. We thank Messrs Aarre Valkonen, Olavi Järvinen and Pekka and Juha Manninen for catching the fish for this study. Mr Malcolm Hicks (M.Sc.) kindly checked the English of this manuscript and Mr Markku Julkunen (M.Sc.) helped with the statistics

\section{LITERATURE CITED}

Agius, C. (1980). Phylogenetic development of melanomacrophage centres in fish. J. Zool. 191: 11-31

Agius, C. (1981). Preliminary studies on the ontogeny of the melano-macrophages of the teleost hemopoietic tissues and age-related changes. Dev, comp. Immunol. 5: $597-606$

Agius, C. (1985). The melano-macrophage centres of fish: a review. In: Manning, M. J., Tatner, M. F. (eds.) Fish immunology. Academic Press, London, p. 85-105

Braun-Nesje, R., Kaplan, G., Seljelid, R. (1982). Rainbow trout macrophages in vitro: morphology and phagocytic activity. Dev. comp. Immunol. 6: 281-291

Brummer-Korvenkontio, H., Valtonen, E. T., Pugachev, O. N. (1991). Myxosporea parasites in roach, Rutilus rutilus (Linnaeus), from four lakes in Central Finland. J. Fish Biol. 38: $573-586$

Cimini, V., Maresca, A., Tajana, G., Tota, B. (1977). On the heterogeneity of the fish heart ventricle. I. Preliminary morphological observations. Boll. Soc. ital. Biol, sper. 53: $543-548$ 
Dinarello, C. A. (1989). The endogenous pyrogens in hostdefense interactions. Hospital Practice 24: 111-128

Ferguson, H. W. (1989). Cardiovascular system. In: Systemic pathology of fish. A text and atlas of comparative tissue responses in diseases of teleosts, 1st edn. Iowa State University Press, Ames, p. 104-124

Graham, S., Secombes, C. J. (1990). Cellular requirements for lymphokine secretion by rainbow trout Salmo gairdneri leucocyte. Dev. comp. Immunol. 11: 59-68

Granberg, K., Hakkari, M., Palomäki, A. (1987a). Limnological studies of the watercourse Äänekoski in 1986. Rep. Inst. Environ. Res., Univ, of Jyväskylä, (in Finnish)

Granberg, K., Hynynen, J., Meriläinen, J. J., Mäkelä, $H_{\text {. }}$ Palomäki, A., Bibiceanu, S. (1987b). Limnological studies of the watercourse Äänekoski in 1987 Rep. Inst. Environ. Res., Univ. of Jyväskylä, (in Finnish)

Grant, R. T., Regnier, M. (1926). The comparative anatomy of the cardiac coronary vessels. Heart 13: 285-317

Körting, W., Hofimann, R., Neukirch, M., Fuhrmann, $I$. (1984). Myxosporidien-bedingte Schwimmblasenentzündung bei Karpfenbrut. Berl. Münch. tierärztl. Wochenschr. 97: 99-104

Overstreet, R. M., Koie, M. (1989). Pearsonellum corventum, gen. et sp. nov. (Digenea: Sanguinicolidae), in serranid fishes from the Capricornid section of the Great Barrier Reef. Aust. J. Zool. 37: 71-79

Overstreet, R. M. Thulin, J. (1989). Response by Plectropomus leopardus and other serranid fishes to Pearsonellum corventum (Digenea: Sanguinicolidae), including melanomacrophage centers in the heart. Aust. J. Zool. 37: $129-142$

Paasivirta, J., Knuutinen, J., Knuutila, M., Maatela, P.,
Pastinen, O., Virkki, L., Paukku, R., Herve, S. (1988). Lignin and organic chlorine compounds in lake water and the role of the chlorobleaching effluents. Chemosphere 17: $147-158$

Roberts, R. J. (1975). Melanin-containing cells of teleost fish and their relation to disease. In: Ribelin, W. E., Migaki, G. (eds.) The pathology of fishes. University of Wisconsin Press, Madison, p. 399-423

Roberts, R. J. (1989). Fish pathology. Bailliere Tindall, London

Santer, R. M. (1985). Morphology and innervation of the fish heart. Advances in anatomy, embryology and cell biology 89. Springer-Verlag, Berlin

Tota, B., Cimini, V., Salvatore, G., Zummo, G. (1983) Comparative study of the arterial and lacunary systems of the ventricular myocardium of elasmobranch and teleost fishes. Am. J. Anat. 167: 15-32

Valtonen, E. T., Koskivaara, M. (1989). Effects of effluent from a paper and pulp mill on parasites of the roach in central Finland. In: Bauer, O. N. (ed.) Parasites of freshwater fishes of North-West Europe. Institute of Biology, USSR. Academy of Sciences, Karelian Branch, Petrozavodsk, p. 163-168

Wedemeyer, G. A. (1976). Physiological response of juvenile coho salmon (Oncorhynchus kisutch) and rainbow trout (Salmo gairdneri) to handling and crowding stress in intensive fish culture. J. Fish. Res. Bd Can. 33: 2699-2702

Weeks, B. A., Warinner, J. E., Mason, P. L., McGinnis, D. S. (1986). Influence of toxic chemicals on the chemotactic response of fish macrophages. J. Fish Biol. 28: 653-658

Wiederholm, $T$ (1980). Use of benthos in lake monitoring. J. Wat. Pollut. Control Fed. 52:537-543

Manuscript first received: January 15, 1993

Revised version accepted: June 10,1993
Responsible Subject Editor: C. B. Schreck, Corvallis,

Oregon, USA 